\title{
Multidisciplinarity in an inclusive support system $^{1}$
}

Streszczenie: Artykuł przedstawia częściowe rezultaty projektu pt. „Szkoła otwarta dla wszystkich" realizowanego w przedszkolach i szkołach podstawowych we wszystkich okręgach Republiki Słowackiej, z wyjątkiem powiatu bratysławskiego, w okresie od 1.02.2016 r. do 30.11.2019 r. Celem projektu było wsparcie edukacji włączającej dzieci z defaworyzowanych społecznie i/ lub zmarginalizowanych społeczności romskich przed rozpoczęciem nauki w szkole. Autorka analizuje efekty realizowanego programu edukacyjnego, wskazuje mocne i słabe strony współpracy interdyscyplinarnego zespołu (pracowników pedagogicznych, specjalistów, rodziców) w zakresie wsparcia uczniów ze szkół podstawowych.

Słowa kluczowe: szkoła podstawowa, zespół interdyscyplinarny, zintegrowany system wsparcia, edukacja włączająca, dzieci romskie

\section{Introduction}

Each school should be open to all pupils living in a particular area and should guarantee their right to high-quality education. An inclusive environment is a natural environment and establishes opportunities for each individual. Variety and diversity are beneficial to the whole. Inclusive education supports the dynamic system of educational and specialized services that flexibly responds to the needs of children, family and teachers. It is a process rather than a state. It implies common education of pupils of unequal capacity, ensuring equal opportunities for them (www.inklukoalicia.sk).

Inclusive systems in and around schools:

- concentrate on supportive, quality learning environments, welcoming and caring schools and classrooms and preventing discrimination,

- address the needs of students in a holistic way,

- recognize students' individual talents and voices,

1 The study is a partial output of the APVV grant project no. 170075 Health education in the education of Roma pupils from socially disadvantaged background. 
- are open to the voices and active participation of parents, multidisciplinary teams and agencies,

- focus on the differentiated needs of marginalized and vulnerable groups,

- covers 7 significant dimensions of inclusive systems,

- synthesizes international research and EU policy,

- is developed for national policy-makers, evaluation experts, regional and local authorities, school leaders and teachers,

- promotes inclusive systems in and around schools (Downes, NairzWirth, Rusinaitè, 2017).

Obviously, the effectiveness of any help is conditioned by cooperation of a multidisciplinary team with a range of expertise who lay emphasis on dialogue, involvement and cooperation. Multidisciplinary collaboration is defined as professionals from across different disciplines, parents, and students working together to achieve the mutual goal of delivering an evidence-based educational program designed to meet individual need and access to the general curriculum. All participating experts are in the position of equal partners of the receiver of care and participate in making decisions on the procedure and implementation of the care. It is crucial to reflect the uniqueness of all pupils and their families.

Team cooperation between various branches of science makes it possible to identify common features of procedures employed in various professions. Specialists who employ this approach draw conclusions in mutual cooperation. An important role is played by reflection of all the participants. Their cooperation is based on shared responsibilities.

A multidisciplinary team at schools is based on cooperation of the pedagogical and specialist staff. The multidisciplinary cooperation of experts facilitates a more comprehensive utilization of their expertise compared to a non-coordinated care in which an individual and his/her family face contradictory expectations and requirements. Individual team members pursue their priorities independent of one another; instead, all of them should understand the objectives in educating each individual student and they should make use of the synergy of expertise and personality.

\section{Survey methodology}

The survey aimed to identify and analyze the effects of the education program Cooperation of pedagogical employees and specialists in the system of 
inclusive pupil support within the national project School open to everybody (hereinafter SOE). We implemented in-depth structured interviews with primary school ${ }^{2}$ (hereinafter PS) managers from March through April 2019.

The survey covered managers of 10 PSs which took part in the SOE national program from 2016 to 2019. The PSs are characterized in Table 1. All these PSs are also places at which the grant project Education to health of Romany pupils from socially disadvantaged environment has been implemented. The project is coordinated by the Pedagogical Faculty, Prešov University in Prešov.

Table 1. Characteristics of the workplace of the in-depth structured interview respondents - primary school manag

\begin{tabular}{|c|c|c|}
\hline \multirow[b]{2}{*}{ District } & \multicolumn{2}{|r|}{ Item: Charakteristics of primary school } \\
\hline & $\begin{array}{l}\text { Proportion of pupils } \\
\text { from MRC (\%) }\end{array}$ & $\begin{array}{c}\text { Number of pedagogical assistants/specialists - } \\
\text { Number, position }\end{array}$ \\
\hline Prešov & $32 \%$ & 3/1 school educationist, 1 social educationist \\
\hline Prešov & $87 \%$ & $\begin{array}{l}\text { 2/1 specialized school educationist, } 1 \text { school speech therapist, } 1 \text { school } \\
\text { educationist }\end{array}$ \\
\hline Prešov & $25 \%$ & 1/1 school psychologist, 1 social educationist \\
\hline Prešov & $89 \%$ & 4/1 medical educationist, 1 social educationist \\
\hline Prešov & $72 \%$ & 5/1 school special educationist, 1 social educationist \\
\hline Košice & $78 \%$ & 4/1 school educationist, 1 social educationist \\
\hline Košice & $43 \%$ & 4/1 school educationist, 2 social educationists \\
\hline Košice & $28 \%$ & 4/1 school special educationist, 1 social educationist \\
\hline Košice & $83 \%$ & $8 / 1$ school educationist, 2 social educationists, 1 school speech therapist \\
\hline Košice & $45 \%$ & 3/1 school special educationist, 2 social educationists \\
\hline
\end{tabular}

Source: Own research.

The multidisciplinary teams which worked at the SOE primary schools consisted of $3-6$ members. The number of team members depended on the school size and reflected the pupils' needs. Villages and small towns face the problem of finding qualified school psychologists and/or specialists. A small number of experts was compensated by school speech therapists.

The work of each expert has its specific features. A multidisciplinary team consists of experts of different specialization and of different track history.

2 Primary school education starts at the age of 6 children. Primary school is divided into two stages. First stage lasts for four years $\left(1^{\text {st }}-4^{\text {th }}\right.$ year of study). Second stage lasts for five years $\left(5^{\text {th }}-9^{\text {th }}\right.$ year of study). After graduating from the primary school children continue their study at secondary school after passing the entrance exam. 
Some of them developed their knowledge and skills within continual education programs. Therefore, they are able to prove their competence with regard to a number of questions and problems and to find effective solutions. Importantly, they are able to come up with new ideas and to violate thinking stereotypes.

The effectiveness of multidisciplinary teams heavily depends on the ability of a class teacher, pedagogical assistant and a specialist staff to cooperate with parents of pupils coming from marginalized Romany communities (hereinafter $\mathrm{MRC}$ ). However, entering into and maintaining the cooperation and partner relationship between the school and the Romany family is not simple nowadays. The cooperation between a teacher and a specialized school educationist is meaningful especially in pupils with special education needs, mainly in the case of learning disorders. Their help is important in preparing pupils for the education process. PS teachers appreciate the help of specialized school educationists in mastering various adaptation problems at the beginning of school attendance and in developing individual education programs.

A school psychologist can significantly help a pupil in solving various education problems and in eliminating social-pathological phenomena, and in the implementation of preventing programs - ideally within multidisciplinary teams. Social educationists can relieve class teachers of terrain work. In addition, they communicate with pupils' legal representatives and various institutions as well as visit pupils' families. In the countries where social work is considered to be an inherent part of the education system, social workers are members of a multidisciplinary school team. The primary objective of social work at school is prevention and intervention in the field of problem behaviour of children, family strengthening in solving social problems, and establishing open communication between a school and a pupil's family.

\section{Analysis and interpretation of education program effects}

The development and implementation of a program of continual education of pedagogical employees and specialists labeled as the Cooperation of pedagogical employees and specialists in the system of inclusive pupil support followed from the requirements of the governmental program School open to everybody ${ }^{3}$, in particular, its point 3.1.1. Development of a continual edu-

3 The project School open to everybody was implemented in kindergartens and primary schools in all districts of the Slovak Republic, with the exception of Bratislava 
cation program. The program reflected and drew on the implementation of inclusive education within the former governmental projects: Inclusion of marginalized Romany communities through education of pedagogical employees (MRC 1), Inclusive model of education at pre-primary level of the education system (MRC 2), and the Project of inclusive education (PRINED).

The evaluation of the education program Cooperation of pedagogical employees and specialists in the system of inclusive pupil support is of the summarizing type, i.e., one following the end of intervention. A summarizing evaluation is usually aimed at the assessment of the intervention results, summarizing the observations and findings and taking decisions on continuation, replication and/or extension of the intervention. A summarizing evaluation is important for an effective use of public sources.

The updating education program Cooperation of pedagogical employees and specialists in the system of inclusive pupil support pursues the preparation of pedagogical and specialized employees for effective and open multidisciplinary communication and cooperation with the aim of facilitating the adaptation of the inclusive education model. The main objective of the model was to update professional competences of pedagogical and other specialists, to develop their pedagogical and specialized knowledge and skills in the field of cooperation, with the aim of implementation of practical adaptation of an

district, in the period from 01.02.2016 to 30.11.2019. The Project reflected the results of three former projects guaranteed by the Methodological-pedagogical centre in Bratislava. Its uniqueness consisted in establishing an effective model of cooperation among several education system components, i.e., support to and cooperation between pedagogical workers and specialists at kindergartens and primary schools, including pedagogical assistants, specialists from pedagogical and psychological consulting and preventing centres, teachers in charge of informal education of pre-school age children outside the education system, and tutors (children's parents). The strategic objective of the governmental project School open to everybody was support to inclusive education, improved cooperation with families (both majority and minority population), the education aimed at cooperation between pedagogical employees and specialists in kindergartens and primary schools, an improved inclusive approach to education, informal education as a tool for the prevention of unjustified placement of children in special schools, improved preparation of children from a socially disadvantaged environment and/or marginalized Romany communities before they start to attend a school, involvement of parents and their children, multidisciplinary - inclusive teams, a full day education system, improved expertise of pedagogical workers and specialists in the field of inclusive education, and material support to kindergartens and primary schools. 
inclusive education model in the school environment in the best possible way.

Continual education of pedagogical employees and specialists is a process of continuous acquisition of knowledge, skills and abilities by participants of continual education in order to complete, extend and update their qualification as a precondition for a high-quality performance of pedagogical and specialized activities. Continual education enables pedagogical employees and specialists to meet the requirements related to their professional career progress and/or to upgrade their expertise (www.minedu.sk). Continual education in a regional education system can be implemented by various institutions. The most prominent one is the Methodological-Pedagogical Centre (MPC) which, in the current system, assumes a privileged position relative to the other institutions because it is directly financed from the governmental budget.

The interviewed school managers agree on the fact that the participation of pedagogical workers and specialists and their requalification (cooperation of pedagogical workers and specialists) contributes to the development of school, to the development and/or modification of a school education program, and to the identification of a school's education objectives and priorities. They are of the view that joint education of pedagogical workers and specialists is an important factor in inclusive education. However, none of the interviewed respondents could demonstrate that the participation of pedagogical workers and specialists in the education program improved the effectiveness, open communication and cooperation of the multidisciplinary team.

The managers appreciate the fact that the updating education program Cooperation of pedagogical employees and specialists in the system of inclusive pupil support was implemented directly at schools. Hence, the schools did not have to cover the cost of transportation of their employees and could avoid seeking substitute teachers for that period.

\section{Discussion}

School is an environment or a group of people that - irrespective of their differences - can appreciate the differences. This fact enables them to effectively and openly communicate and cooperate in pursuing common objectives. School should be an organization which directly contributes to the integration of all pupils into the process of learning via communication and 
cooperation with its partners. The work with Romany pupils who come from MRCs can only be successful if it integrates both a narrower community (pedagogical and non-pedagogical employees and specialists) and a broader community (parents, consulting institutions, social workers, institutions and organizations that deal with the problems of socially marginalized families, activation workers from that community, etc.).

The $₫ 5$, Section 2 of the Law of the education system administration maintains that the school is directed by a manager, and explicitly specifies the manager's responsibilities. The manager is responsible, inter alia, for the preparation and implementation of an annual plan of the education of pedagogical employees; annual evaluation of pedagogical employees and specialists; and for the quality of education at school. $\mathbb{\$} 5$, Sections 3 and 4 of the law state that the manager is in charge of the administration and makes decisions on individualized education of pupils and on individualized curricula of pupils (law of the education system administration and school selfadministration). The interviews with the school managers suggest that they usually do not have sufficient space for the human resource management in relation to the process of development, implementation and evaluation of individualized education programs. It follows from the survey that the existing system does not provide schools relevant conditions for an effective work of multidisciplinary team members (e.g., appropriate management strategies, communication skills, and conflict-solving skills).

Multidisciplinary teams do not have common strategies and, if they are available, they do not have a sufficient time space for their implementation and for the utilization of common resources and information about pupils with who they work. This precludes them from making use of the advantages of a harmonized support. Due to their other duties, mostly bearing on financial issues, the managers cannot interconnect the school development requirements with the requirements of education of pedagogical employees and specialists. In their view, systematic intervention is more effective if implemented by multidisciplinary teams and/or if external experts participate in this process. Its effectiveness is thus conditioned by the involvement of all those who can affect this process, including family members, siblings, volunteers, etc.

We believe that the existing situation has resulted from the lack of systematic and annually updated educational priorities in the pedagogical-organizational instructions. A centralized guidance and instructions limited to a single year eliminate creative team activities, which results in uncertainty 
and the lack of systematic management. A school open to everybody is an institution in which the key principle is a multidisciplinary approach to the elimination of any obstacles and hindrances in the education and learning processes, and which supports integration of every participant in the education process. This education mission presupposes a real and substantial change. It is necessary to consider a functional autonomy of schools that carry out regional education policy and are in a position to address the education system in an appropriate way.

The establishment of effective and targeted multidisciplinary teams at primary schools is an opportunity to contribute to the solution of everyday education problems that arise in work with pupils, including those problems pointed out by the interviewed school managers: the lack of pupils' interest in the tuition process, their failure to prepare homeworks and school aids and/or their failure to prepare for classes; attendance problems; inappropriate behavior; inappropriate hygienic/dietary habits; poor cooperation with pupil's family.

One of the most serious obstacles to the establishment of multidisciplinary teams at standard primary schools is the shortage of teacher's assistants and specialists - school psychologists, specialized school educationists, medical and social educationists, and speech therapists. Only one in fourteen primary schools in Slovakia employs a school psychologist, and only one fifth of these schools employ a specialized school educationist. These numbers at kindergartens and secondary schools are even much worse. In addition, schools would benefit from a more comprehensive support in integrating pupils with diverse needs. This support includes education of pedagogical workers and a specialist staff on the basis of well-defined standards and job contents for the individual team members as well as an accessible high-quality consultancy services (Hapalová, 2018).

The survey results show that the governmental project School open to everybody has only partly supported the model of inclusive education at primary schools. European funds are not sufficient for the solving of the problem of segregated education of pupils coming from Romany communities. The primary school should be able (given its opportunities and competences in making decisions on the objectives, contents and organization of education) to reflect its own needs and the needs of the region. In the existing system of education, it is not flexible enough in the field of human resources, in establishing partnership at the school and regional levels, in providing support services for schools and pupils, nor in establishing an open education 
system at a particular location. We miss a connection between schools and the central administration of education in the form of a natural association of regional schools. Such an association can guarantee a meaningful education policy (obviously, with an appropriate and balanced governmental support).

\section{Conclusion}

The system of education is a complicated process. In Slovakia, there has not been any serious discussion of multidisciplinary teams for the sake of implementation of inclusive education. The existing education policy does not enable schools to establish a flexible education environment. We should seek inspiration in some other countries. Austria and Great Britain, for example, establish clusters and campuses (at the level of a town or a rural region). Clusters are not intended to be free associations of existing schools. They are based on association of at least two and at most eight schools. They postulate a change at the management level - rather than school it is the cluster that is the basic unit of the system. A cluster can encompass all school levels of the region (including pre-school establishments) and can make it possible to develop a reasonable and targeted education policy. Multidisciplinary teams are required to take part in intervention at various levels - individuals, groups, classes, schools, families, communities. Depending on the specific situation, multidisciplinary teams are established within the existing community structures, organizations and towns - in relation to the context of the area and the local environment.

\section{Bibliography}

McCausland, D. 2005. International Experience in the Provision of Individual Education Plans for Children with Disabilities, p. 65. https://www. researchgate.net (6.05.2020).

Downes, P., Nairz-Wirth, E. and Rusinaite, V. 2017. Structural Indicators for Inclusive Systems in and around Schools. NESET II Report. Luxembourg: Publications Office of the European Union.

Hapalová, M. 2018. Inklúzia ako filozofia, ktorá ovplyvňuje každé diet’a. https://www.ucn.sk/ (6.05.2020).

Zákon o štátnej správe v školstve a školskej samospráve. https://www.direktor.sk (6.05.2020). 


\title{
Multidisciplinarity in an inclusive support system
}

\begin{abstract}
Complex phenomena of our world cannot be successfully explored from the perspective of isolated fields of science. What is therefore needed is a synthesizing approach. The cooperation of a multidisciplinary team at a primary school should be focused on the identification and elimination of the problematic areas of education. The establishment and support of multidisciplinary teams requires strategic planning by a school management. Any such team should approach pupils' needs in a coherent way. This paper concerns the effects of the education program and identifies strong and weak points in cooperation of multidisciplinary team members at primary schools. The author presents the results of a survey in-depth structured interviews with managers of primary schools participating in the education program Cooperation of pedagogical employees and specialists in the system of inclusive pupil support within the governmental project School open to everybody.
\end{abstract}

Keywords: primary school, multidisciplinary team, inclusive education, student support services, pedagogical and specialized employees, continual education

Translated by Alica Petrasová 